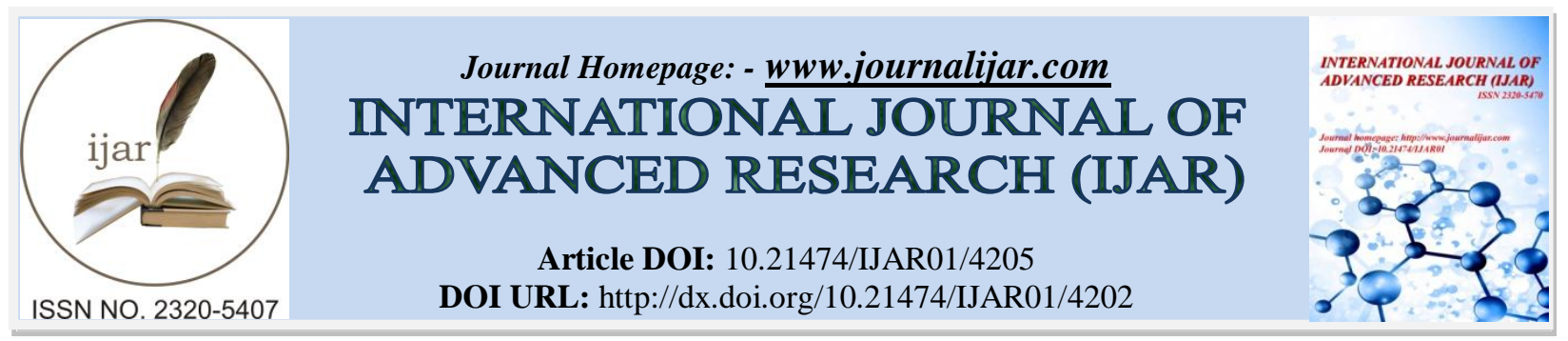

RESEARCH ARTICLE

\title{
TEACHER-RELATED FACTORS INFLUENCING ACADEMIC PERFORMANCE OF PUPILS ON TRANSITION FROM STANDARD THREE TO STANDARD FOUR IN PUBLIC PRIMARY SCHOOLS IN KENYA.
}

Hesbon M. Obaga, Susan J. Kurgat (PhD) Chris Mukwa (Prof).

Department of Curriculum Instruction and Education Media, Moi University, Eldoret, Kenya.

\section{Manuscript Info}

Manuscript History

Received: 15 March 2017

Final Accepted: 13 April 2017

Published: May 2017

Key words:-

Academic Performance, Transition

Form, Standard Three, Standard Four

\begin{abstract}
The purpose of this paper is to determine teacher-related factors that affect academic performance of pupils on transition from standard three to standard four in public primary schools. The paper is guided by transition theory, which was developed by Schlossberg. The study was conducted at Lugari Sub-County. The study findings revealed that teacher related competencies like; qualification, experience, teaching methods and level of commitment influenced pupils' academic performance. The study recommends that more teachers need to undergo in-service training, teachers need to improve their relationship with pupils, government should employ more teachers, and curriculum supervisor should regularly monitor and evaluate teachers in schools.
\end{abstract}

Copy Right, IJAR, 2017,. All rights reserved.

\section{Introduction:-}

Education is a critical component for economic development of a country (Dahir, 2013). The quality and level of education in a country determines the wealth of its people. Quality education is widely known to improve people's quality of life, supports co-operation and compassion within a society. Education plays a key role in the economy through development of human and social capital, which is key ingredients in the development of a country as reported by (Ruto, 2014). According to Turnbull (2006), transition periods represent times of potential challenge. The discontinuity between prior to lower and upper primary settings is one of many complex differences that children must adapt when they transit upper primary school. For example, primary schools are usually larger spaces, with more buildings and larger play areas than prior to school settings (Margetts, 1999 in Hirst, Jervis, Visagie, Sojo, Cavanagh, 2011). For instance, in upper primary, Hirst et al., (2011) observed that there are often higher ratios of children to adults, while socially, children may have to make new friends (Dockett \& Perry, 2006). There is a shift from a socially oriented educational approach that was used in lower primary to a cognitively oriented approach to teaching and learning (Ladd, Herald \& Kochel, 2006; Margetts, 2009).

The study adopted Schlossberg's theory is typically categorized as a theory of adult development; however, the theory is also relevant to other aged students. Describing her model as a vehicle for analyzing human adaptation to transition, Schlossberg asserted that adaptation was affected by the interaction, characteristics of the pre - transition and post transition environments, and characteristics of the individual experiencing the transition (Evans, Forney, Guido, Patton \& Renn, 2010). The model was developed to create a framework in which practitioners would be able to understand why people react and adapt so differently at different points in life.

Corresponding Author: - Hesbon M. Obaga.

Address: - Department of Curriculum Instruction and Education Media, Moi University, Eldoret, 
One major responsibility of teachers is to ensure that pupils do not feel marginalized. One of the ways that this can be achieved is through our interventions and by continuously assessing the school climate. It is also important for teachers to be able to process and understand the information gathered from the pupils that are going through the transitions, while understanding the relationship between the pupils and their environment. Also significant is the interaction between factors in persons, their immediate family/community environment and their societal landscape. Changes or conflict in any one layers. To understand the pupil's transitions then, we must look not only at the pupils and their immediate environment, but also at the interaction of the larger environment as well. The study identified that the impact of these factors remains unclear in sub Saharan .

In recent years, there has been an increased focus on the transition period and the preparation required of children, schools and teachers to facilitate a successful and positive transition experience for children as they enter upper primary (CEIEC in Hirst et al., 2011). Supporting pupils as they navigate the transition to upper primary school has the potential to aid their social, emotional and cognitive development, as well as to equip children with invaluable skills that can help them to deal more effectively with the many additional challenges and transitions that lie ahead in their journey to completion of basic education.

However, research conducted in Kenya shows that standard three children transiting to standard four performances is greatly affected. According to Uwezo (2012) policy brief, there has been chronic deficiency in learning outcomes across Kenya. for instance, less than one out of three children enrolled in standard three are able to pass both English and numeracy tests set at the standard 2 level; and less than half of all pupils in standard four can also pass both tests. The report further noted that many factors explain the differences in learning outcome. Osero, Abobo and Orodho (2015) found out that the standard three pupils' performance lowers as they enter standard four compared to performance in standard one, two or three (lower primary) indicating that there is a significant impact on transition. In Lugari Sub County, For many years performance in standard four in exams by pupils on transition from standard three has been dropping. The table below presents Lugari Sub-County Joint Evaluation Exam Results for second term year 2012 to 2014 .

Table 1:- Joint Evaluation Exam Results for second term year's 2012 to 2014

\begin{tabular}{|l|l|l|}
\hline Class & Std 3 & Std 4 \\
\hline Year & Mean scores & Mean scores \\
\hline 2012 & 375.68 & 279.34 \\
\hline 2013 & 371.52 & 262.32 \\
\hline 2014 & 376.97 & 260.80 \\
\hline
\end{tabular}

Source: Lugari Sub - County Exam Council Analysis (2014)

From the above table, it is evidently clear that as learners move from standard three to four their exam performance drops. This is an indication of low academic achievement. Even with this data available every year, there appear to be no solution found to reverse trends in pupils drop in academic performance in exam on transition from standard three to standard four hence the low academic achievements. To address this problem of dropping in academic performance of learners on transition to various levels of learning, studies have been done elsewhere on: factors affecting academic performance of learners on transition from pre-primary to primary and from primary to secondary but there are virtually no known studies with regard to transition from standard three to standard four in public primary schools in Kenya. Therefore, the study sought to determine factors influencing academic performance of pupils on transition from standard three to four in Lugari Sub County.

\section{Literature Review:-}

\section{Teacher Characteristics and Academic Achievement:-}

According to Osero, Abobo and Orodho (2015) argued that teachers should ensure they induct the pupils, that is, they should typically provide a variety of programmes intended to orientate pupils to the expectations and operations of the school. The programmes should also provide support for learning and the social and personal aspects of transition. According to Ngaroga (2007) these are attributes which teacher needs to possess for effective performances in the school and these characteristics are not inherent but acquired qualities. A well-trained and certified teacher must show evidence of mastery of subject matter. According to Dunhill (2000), teacher knowledge must be of two-fold nature. A good teacher must first possess a wide general knowledge and within the confines of this general knowledge, a sound understanding of the subject he is to teach in the classroom. Quadrik et al., (2004) 
corroborate that a good teacher must be well knowledge versed in his area of specialization. He must know which to teach, when to teach and how to teach. In the opinion of Obanya (2004), the quantity and quality of the teacher's knowledge will give the teacher enough material and confidence to teach effectively.

\section{Teacher Inherent Characteristics:-}

Teacher inherent characteristics refer to those features of the teacher that are part of his personality and intellectual make up. Male teachers are usually not burdened by households' chores and thus stand a better hence of preparing adequately for their teaching (Obanya, 2004). Age chronological factor could influence the performance of the teacher in the school. Obanya (2004) explained that old teachers are likely to be more stable and devoted to their teaching than younger teachers. Attitudes affect teacher's performance level. Adeyanju et al., (2004) narrated that a teacher who has a positive attitude towards teaching his pupils will obviously teach more effectively than the teacher who has developed negative attitudes towards the learners he has to deal with. A good teacher is one who respects truth, who is sincere in words and acts and whose personal life sets a good example to his pupils. Quadric et al., (2004) contribute that a teacher must be caring, kind and gives equal treatment to all students in his class. According to Adedeji (2007), a knowledge and brilliant teacher will command the respect of learners as well as of the wider society.

\section{Materials and Methods:-}

The study population comprised of the QASOs, primary school head teachers and standard three and standard four primary school teachers in the selected primary schools. Stratified random sampling was used for selecting school for the study; (30\%) public primary school was selecting using proportionate random sampling from the zones. All the QASOs and all standard three and four subject teachers in the selected schools were purposively sampled for inclusion in the study. Head teachers for the selected schools automatically qualified for participation in the study, questionnaires, interview schedule and document analysis were utilized in data collection. Data was analysed using descriptive statistics and content analysis. Analysed data is presented through frequency distribution tables.

\section{Findings and Discussion:-}

The findings of the study follow the research question that was:

What are the teachers -related factors that affect the academic performance of pupils on transition from standard three to standard four in public primary schools?

\section{Teachers-Related Factors Affecting Academic Performance of Pupils on Transition from Standard Three to Standard Four}

The study sought the following information from head teachers, standard three and four teachers; job designation, gender, age brackets and education levels of respondents. Table 1 shows the results on teachers' gender.

Table 2:- Gender of Respondents

\begin{tabular}{|l|l|l|l|l|l|l|}
\hline & \multicolumn{2}{|c|}{ Class three teachers } & \multicolumn{2}{l|}{ Class four teachers } & \multicolumn{2}{l|}{ Headteachers } \\
\hline Gender & $\mathbf{F}$ & $\mathbf{\%}$ & $\mathbf{F}$ & $\mathbf{\%}$ & $\mathbf{F}$ & \% \\
\hline Male & $\mathbf{8}$ & 3.9 & 38 & 48.6 & 10 & 76.9 \\
\hline Female & 18 & 69.1 & 40 & 51.4 & 3 & 23.1 \\
\hline Total & $\mathbf{2 6}$ & $\mathbf{1 0 0 . 0}$ & $\mathbf{7 8}$ & $\mathbf{1 0 0}$ & $\mathbf{1 3}$ & $\mathbf{1 0 0 . 0}$ \\
\hline
\end{tabular}

Table 2 shows that most $18(69.1 \%)$ of respondents in class three were females while male constituted $8(30.9 \%)$. For class four teachers, $38(48.6 \%)$ were male and $40(51.4 \%)$ female. For head teachers, 10 (76.9\%) were male while $3(23.1 \%)$ were female. This shows underrepresentation of women in school headship positions in Lugari Sub County.

Table 3:- Age of Respondents

\begin{tabular}{|l|l|l|l|l|l|l|}
\hline & \multicolumn{2}{|c|}{ Class three teachers } & \multicolumn{2}{l|}{ Class four teachers } & \multicolumn{2}{l|}{ Headteachers } \\
\hline Age of responders & $\mathbf{F}$ & $\%$ & $\mathbf{F}$ & $\%$ & $\mathbf{F}$ & $\%$ \\
\hline 25 and below & 1 & 3.8 & 12 & 15.4 & 0 & 0.0 \\
\hline $26-35$ & 4 & 15.4 & 16 & 20.5 & 1 & 7.7 \\
\hline $36-45$ & 5 & 19.2 & 31 & 39.7 & 2 & 15.4 \\
\hline
\end{tabular}




\begin{tabular}{|l|l|l|l|l|l|l|}
\hline $46-55$ & 6 & 23.1 & 10 & 12.8 & 4 & 30.8 \\
\hline 56 and above & 10 & 38.5 & 9 & 11.5 & 6 & 46.2 \\
\hline Total & $\mathbf{2 6}$ & $\mathbf{1 0 0 . 0}$ & $\mathbf{7 8}$ & $\mathbf{1 0 0 . 0}$ & $\mathbf{1 3}$ & $\mathbf{1 0 0 . 0}$ \\
\hline
\end{tabular}

Findings show that for class three teachers, $10(38.5 \%)$ were aged 56 years and above, $6(23.1 \%)$ were between 46 55 years, $5(19.2 \%)$ were $36-45$ years, $4(15.4 \%)$ were aged $26-35$ years and only $1(3.8 \%)$ were found to be aged 25 years and below. This shows that most $21(80.8 \%)$ of class three teachers are aged more than 36 years. For class four teachers, $31(39.7 \%)$ were aged 36-45 years, $16(20.5 \%)$ were aged $26-35$ years, $12(15.4 \%)$ were aged 25 years and below, $10(12.8 \%)$ were aged $46-55$ years and $9(11.5 \%)$ were found to be above 56 years of age. The findings shows that even the class four teachers, most $50(64.0 \%)$ were aged 36 years and above. Response from heads also showed that most of them were aged more than 36 years. This is an indication of highly experienced people who can supervise transition process well. Dahir (2013) explained that teacher under this age category may have been teachers for a long time and hence have the information regarding the factors that influence pupil transition from primary to secondary levels of education. The above findings are in agreement with (Obanya, 2004) who explained that old teachers are likely to be more stable and devoted to their learners than younger teachers. Age in the service or years of teaching experiences essentially determines teachers' effectiveness. Apart from the rich experience, which older teachers have acquired, they are more likely to stay longer in the teaching profession than younger teachers are. It is however, the qualitative experience of the older teacher that can make him effective in the classrooms and not simply the number of years he has spent on the job.

Table 4:- Respondents Job Designation

\begin{tabular}{|l|l|l|l|l|}
\hline & \multicolumn{2}{|l|}{ Class three teachers } & \multicolumn{2}{l|}{ Class four teachers } \\
\hline Job designation & $\mathbf{F}$ & $\mathbf{\%}$ & $\mathbf{F}$ & \% \\
\hline Assistant teachers & 13 & 50.0 & 65 & 83.3 \\
\hline Senior teachers & 13 & 50.0 & 13 & 16.7 \\
\hline Total & $\mathbf{2 6}$ & $\mathbf{1 0 0 . 0}$ & $\mathbf{7 8}$ & $\mathbf{1 0 0 . 0}$ \\
\hline
\end{tabular}

Finding in Table 4 indicates that majority of the respondents were assistant primary school teachers who comprised $13(50 \%)$ of total sample in class three $65(83 \%)$ in class four. Senior teachers on the other hand constituted 13 $(50 \%)$ of the sampled respondents in class three and $13(16.7 \%)$ in class four. In line with the purpose of this study, it is observed that teachers play a more significant role in the academic performance of pupils as compared to the role played by head teachers. This call for co-operation between the headteachers and teachers working under them to ensure effective curriculum implementation. This will be a key factor determining learners' transition from standard three to four. The prospective teacher must have the required knowledge, skill and methodology for any impressive performance that majorly depends on ones academic and professional qualifications (Osero, 2012).

Table 5:- Level of Education of Respondents

\begin{tabular}{|l|l|l|l|l|l|l|}
\hline & \multicolumn{2}{|c|}{ Class three teachers } & \multicolumn{2}{l|}{ Class four teachers } & \multicolumn{2}{l|}{ Headteachers } \\
\hline Level of education & $\mathbf{F}$ & $\mathbf{\%}$ & $\mathbf{F}$ & $\mathbf{\%}$ & $\mathbf{F}$ & \% \\
\hline P1 & 7 & 26.9 & 36 & 46.2 & 2 & 15.4 \\
\hline ATS4 & 13 & 50.0 & 16 & 20.5 & 6 & 46.2 \\
\hline ATS1 & 3 & 11.5 & 9 & 11.5 & 3 & 23.1 \\
\hline Diploma & 2 & 7.7 & 11 & 14.1 & 1 & 7.7 \\
\hline Degree & 1 & 3.8 & 6 & 7.7 & 1 & 7.7 \\
\hline Total & $\mathbf{2 6}$ & $\mathbf{1 0 0 . 0}$ & $\mathbf{7 8}$ & $\mathbf{1 0 0 . 0}$ & $\mathbf{1 3}$ & $\mathbf{1 0 0 . 0}$ \\
\hline
\end{tabular}

Findings in Table 5 shows that half $13(50.0 \%)$ of class three teachers had ATS4 level of education, 7 (26.9\%) were P1 holders, 3 (11.5\%) had ATS, 2 (7.7\%) had diploma while 1 (3.8\%) had degree. For standard four teachers, 36 (46.2\%) were P1 holders, 16 (20.5\%) had ATS4 level of training, 11 (14.1\%) had diploma, 9 (11.5\%) were at ATS1 level and only $6(7.7 \%)$ reported to have degree. The findings shows that class four teachers are advancing in their education level as a significant number of them appeared to have diploma and degree as opposed to standard three teachers. The head teachers responses shows that close to half $6(46.2 \%)$ had ATS4 level of qualification, 3 (23.1\%) had ATS1, 2 (15.4\%) were PI holders while 2 (15.4\%) had degree and diploma. This shows that heads have low 
academic qualifications as opposed to teachers and this may affect supervision and curriculum implementation in schools. From the above analysis, it can therefore be concluded that most teachers especially those teaching in class four have made an effort of furthering in their education hence can affect positively academic performance in public primary schools. Osero (2012) said that teachers' further education and training has been made possible through school-based programmes that are offered by institutions of higher learning, that is, universities. Osero concluded that neither academic qualification nor professional were causes of good performance of pupils in lower primary and poor performance of pupils in upper primary but rather some other factors. Moreover, this finding is in agreement with Tella (2007) who asserted that a knowledgeable and brilliant teacher will command the respect of learners as well as of the wider society and will be able to deliver quite effectively. The consequence of teachers not advancing their education could explain poor performance of learners in classroom. This was observed by Dahir (2013) who found out that lack of training among the teachers may affect pupils' performance and hence minimize the pupils' chances of transiting from primary to secondary education at Daadab refugee camp. After ascertaining teachers' education level, another aspect that the research studied was length of services.

Table 6:- Length of Service of Respondents

\begin{tabular}{|l|l|l|l|l|l|l|}
\hline & \multicolumn{2}{|c|}{ Class three teachers } & \multicolumn{2}{l|}{ Class four teachers } & \multicolumn{2}{l|}{ Headteachers } \\
\hline Length of service & $\mathbf{F}$ & $\mathbf{\%}$ & $\mathbf{F}$ & $\mathbf{\%}$ & $\mathbf{F}$ & $\mathbf{\%}$ \\
\hline Less than 3 yrs & 1 & 3.8 & 20 & 25.6 & 0 & 0.0 \\
\hline 4-6 years & 6 & 23.1 & 30 & 38.5 & 1 & 7.7 \\
\hline 7-9 years & 7 & 26.9 & 15 & 19.2 & 2 & 15.4 \\
\hline Above 10 years & 12 & 46.2 & 13 & 16.7 & 10 & 76.9 \\
\hline Total & $\mathbf{2 6}$ & $\mathbf{1 0 0}$ & $\mathbf{7 8}$ & $\mathbf{1 0 0}$ & $\mathbf{1 3}$ & $\mathbf{1 0 0}$ \\
\hline
\end{tabular}

Findings in Table 6 shows that for class three teachers, 12 (46.2\%) had worked for 10 years and above, 7 (26.9\%) had worked for 7-9 years, $6(23.1 \%)$ for 4-6 years and 1 (3.8\%) had worked for less than 3 years. For class four teachers, $30(38.5 \%)$ had a teaching experience of 4-6 yeas, $20(25.6 \%)$ for less than 3 years, $15(19.2 \%)$ for 7-9 years and $13(16.7 \%)$ for more than 10 years. findings from head teachers in their headship experience, $10(76.9 \%)$ had worked for more than 10 years, 2 (15.45) for 7-9 years while $1(7.7 \%)$ had worked for 4-6 years. The number of years that head teachers and teachers have been working is significant in their understanding of factors influencing transition of pupils from lower primary to upper primary. This view is support by Dunhill (2000) Dahir (2013) who asserted that teachers who have taught for longer period have a lot of experience and they understand learners' individual differences better than those with shorter learning experience do.

On teacher related factors influencing academic performance on learner transiting from lower to upper primary, class three, four teachers together with head teachers were asked to indicate the extent to which they applied the following; discussion, demonstration, explanation and activities.

Table 7:- Teaching Methodologies used by Teachers

\begin{tabular}{|l|l|l|l|l|l|l|}
\hline & \multicolumn{2}{|c|}{ Class three teachers } & \multicolumn{2}{l|}{ Class four teachers } & \multicolumn{2}{l|}{ Headteachers } \\
\hline Teaching methodologies & $\mathbf{F}$ & $\mathbf{\%}$ & $\mathbf{F}$ & $\mathbf{\%}$ & $\mathbf{F}$ & $\mathbf{\%}$ \\
\hline Discussion & 3 & 11.5 & 16 & 20.5 & 4 & 30.8 \\
\hline Demonstration & 6 & 23.1 & 21 & 26.9 & 2 & 15.4 \\
\hline Explanation & 3 & 11.5 & 32 & 41.1 & 6 & 46.2 \\
\hline Activities & 14 & 53.8 & 9 & 11.5 & 1 & 7.7 \\
\hline Total & $\mathbf{2 6}$ & $\mathbf{1 0 0 . 0}$ & $\mathbf{7 8}$ & $\mathbf{1 0 0 . 0}$ & $\mathbf{1 3}$ & $\mathbf{1 0 0 . 0}$ \\
\hline
\end{tabular}

For class three teachers, more than $14(53.8 \%)$ said that they used activity method, 6 (23.1\%) used demonstration, 3 (11.5) utilised discussion while $3(11.5 \%)$ said they used explanation method. For class four teachers, the dominant method that they used was explanation $32(41.1 \%)$, followed by demonstration 21 (26.9\%), then discussion 16 $(20.5 \%)$ and lastly activity method $9(11.5 \%)$. The result shows that there is variation in teaching methods used by class three and four teachers. For class three, activity method dominates while in class four-explanation method featured most. Moreover, response from head teachers showed that $6(46.2 \%)$ said that explanation method is commonly used followed by discussion $4(30.8 \%)$, demonstration $2(15.4 \%)$ and they rated activity method as least 
$1(7.7 \%)$. The results show that teachers in class three in public primary schools in Lugari Sub-County preferred to use activities more frequently since pupils understand better as compared to class four where majority uses explanation methods. In class three pupils, understand better, when they perform some activities in the class hence this contributes positively on the academic performance of pupils on transition from standard three to standard four in public primary schools.

However, as they move to class four majority of the teachers' uses explanation method to teach this is not a very good method of teaching pupils since it denies them the opportunity to perform activities in the classroom hence making them to forget what they learn and therefore performing poorly in the exams. Leading to drop in academic performance of pupils on transition from standard three to standard four in public primary schools in Lugari Sub County. The findings are in agreement with Irish Teachers National Organisation (2008) focus group discussions where parents were concerned about children having to get used to a variety of teachers and a variety of subjects. Primary teachers expressed concern about the transition from a more pastoral-based approach in primary school to a more subject-based approach in post-primary school. Smyth et al (2004) reported a substantial group of first-year students experiencing discontinuity in learning experiences between primary and post-primary school and that the curriculum does not follow on naturally from primary level. The majority also saw teaching methodologies as quite different. The above findings concur with Ngaroga (2007) who asserted that for a teacher to deliver effectively he/she should posses some attributes which will enable him be able to teach well and improve the performance of pupils in the schools. Osero (2012) further adds that when teaching and learning strategies are used properly, they make teaching and learning activities interesting, motivating, and more real and enhance understanding. The learner becomes interested in carrying out designated roles in the teaching and learning process. However, Ng'etich et al., (2015) established that most of the teachers did not use the appropriate methods of teaching conflict and conflict resolution which are learner-centred. This affected learners' academic achievement in social studies.

Table 8:- Teachers Commitment to their Work

\begin{tabular}{|l|l|l|l|l|l|l|}
\hline & \multicolumn{2}{|c|}{ Class three teachers } & \multicolumn{2}{l|}{ Class four teachers } & \multicolumn{2}{l|}{ Headteachers } \\
\hline Commitment to work & $\mathbf{F}$ & $\mathbf{\%}$ & $\mathbf{F}$ & $\mathbf{\%}$ & $\mathbf{F}$ & $\mathbf{\%}$ \\
\hline Punctuality & 2 & 7.7 & 20 & 25.6 & 5 & 38.5 \\
\hline Self- driven & 9 & 34.6 & 19 & 24.4 & 4 & 30.8 \\
\hline Preparedness & 11 & 42.3 & 16 & 20.5 & 3 & 23.1 \\
\hline Remedial lessons & 4 & 15.4 & 23 & 29.5 & 1 & 7.7 \\
\hline Total & $\mathbf{2 6}$ & $\mathbf{1 0 0 . 0}$ & $\mathbf{7 8}$ & $\mathbf{1 0 0 . 0}$ & $\mathbf{1 3}$ & $\mathbf{1 0 0 . 0}$ \\
\hline
\end{tabular}

Results from class three teachers shows that $11(42.3 \%)$ of them said that they are usually prepared in their duties, 9 $(34.6 \%)$ said they are self-driven, $4(15.4 \%)$ said that they organised for remedial learning and $2(7.7 \%)$ said that they are always punctual. For class four teachers, the result shows that they were evenly distributed in their commitment in schools through the four areas identified. However, head teachers appeared to be always committed as revealed by $5(36.2 \%)$ of them followed by being self-driven $4(31.5 \%)$, preparedness $3(26.8 \%)$ and the least was on remedial lessons $1(6.5 \%)$. From the study findings it can be deduced that teacher preparation, punctuality and self-drive by the teacher can negatively affect the pupils academic performance if it not well done. These comments are in line with study findings by Komen who maintained that teacher commitment combined with occurrence of a well-designed learning could best be achieved through mobilization of instructional materials such as verbal presentations, use of media and printed communication (Ng'etich et al., 2015).

\section{Conclusion and Recommendations:-}

Results show that respondents had a common opinion on the contribution of teacher-related factors on academic performance of pupils on transition from standard three to four in public primary schools in Lugari Sub County. For instance, teacher demographic characteristics as experience was a significant factor influencing learners who were transiting from lower to upper primary. Teachers who had more years in teaching profession appeared to understand transitional challenges more as opposed to those who had few years in teaching profession. Moreover, the respondents agreed that gender, age or job designation was not a significant factor influence academic performance of pupils on transition from lower to upper primary. Nonetheless, the study established that teacher commitment, level of education and professional competencies were important predictors of learners' academic performance in schools. For instance, teachers who tended to use learner-centred approaches had pupils who transited well as 
opposed to those who relied on old traditional teaching methods. Moreover, teachers who were prepared in their task ensured that their learning went on well and their learners gained enough competencies a supposed to the unprepared one. This led to the deduction that teacher-related factors are a significant factor influencing academic performance of pupils on transition from standard three to four. Teacher-related factor like qualification, experience, level of commitment and method of teaching affected academic performance of learners on transition from standard three to four in public primary schools in Lugari Sub County. Based on the summary and conclusions made in this study the researcher made the following recommendations to various stakeholders:

1. Teachers should be encouraged to further their studies and attend more in-service training programmes to increase their knowledge, skills and capacity in teaching and learning. Their upgrade and acquisition of required competencies will translate to effective classroom learning leading to positive education outcomes by pupils.

2. Teachers and head teachers should be open and be close to learners to ensure they develop positive attitude and personalities towards schooling. This will help them change their mindset on learning and therefore propel them to work hard in their studies. The government should employ more teachers, motivate them well so that they can deliver well, and work more effectively in order to improve the academic performance of pupils.

\section{References:-}

1. Adeyanju, L. (2007). Teachers Perception of the effects and use of learning aids in teaching: a case study of Winneba basic and secondary schools. Ultibase Articles

2. Dahir, M. D. (2013). Factors Influencing Refugee Learners Transition From Primary To Secondary Schools In Dadaab Refugee Camps, Kenya. MA Project, University of Nairobi.

3. Dockett, S., \& Perry, B. (2009). Readiness for school: A relational construct. Australasian Journal of Early Childhood, 34(1), 20-27.

4. Dunhill, J. (2000). A Teacher Training Manual. London: Hodder and Stoughton.

5. Evans, N. J., Forney, D. S., Guido, F. M., Patton, L. D., \& Renn, K. A. (2010). Student development in college: Theory, research, and practice (2nd ed.). San Francisco, CA: Jossey-Bass.

6. Hirst, M., Jervis, N., Visagie, K., Sojo, V. \& Cavanagh, S. (2011). Transition to primary school: A review of the literature. Commonwealth of Australia.

7. Ladd, G. W., Herald, S. L., \& Kochel, K. P. (2006). School readiness: Are there social prerequisites? Early Education and Development, 17, 115-150.

8. Margetts, K. (2007). Understanding and supporting children: shaping transition practices. In A. H. Dunlop \& H. Fabian (Eds.), Informing transitions: bridging research, policy and practice (pp. 107-199). London: Open University Press.

9. Margetts, K. (2009). Transition to School - Professional Development Session for Families. NSW Illawarra and Shoalhaven.

10. Ng'etich, H. T., Chemwei, B. \& Rotumoi, J. (2015). Instructional Methods Used By Teachers In Teaching Conflict And Conflict Resolution In Primary Schools In Nandi North District, Kenya. International Journal of Contemporary Applied Sciences, 2 (4), 9-23.

11. Ngaroga, J.M. (2007). Revision Education for Primary Teacher Education. Revised Edition. Nairobi: East African Educational Publishers.

12. Obanya. P. (2004). The African Teacher of the 21st Century. Ibadan: Heinemann Educational Books.

13. Osero P. O. \& Orodho, J. A. (2015). School-Based Factors Influencing Performance of Pupils on Transition from Lower Primary to Upper Primary in Ekerenyo Division, Nyamira County, Kenya. Research on Humanities and Social Science, 5 (6), 200-212.

14. Osero P. O. (2012). Factors Influencing Performance of Pupils on Transition from Lower Primary to Upper Primary in Ekerenyo Division, Nyamira County, Kenya. MED Project, Kenyatta University, Kenya.

15. Osero P. O., Abobo, F. \& Orodho, J. A. (2015). Home-Based Factors Influencing Performance of Pupils on Transition from Lower Primary to Upper Primary in Ekerenyo Division, Nyamira County, Kenya. IOSR Journal of Humanities and Social Science (IOSR-JHSS), 20 (4), (5), 33-41.

16. Quadric K. et al (2004). School organization and class management: Theory and practice. Oyo, Tobisic publishers.

17. Ruto, W. (2014). Opening speech during the inauguration of Umma University, Kenya. The Standard, Tuesday Sept 23, 2014.

18. Smyth, K. (2004). The benefits of students learning about critical evaluation rather than being summatively judged. Assessment \& Evaluation in Higher Education, 29(3), 370-378. 
19. Tella, A. (2007). The impact of motivation on student's academic achievement and learning outcomes in mathematics among secondary school students in Nigeria. Eurasia Journal of Mathematics, Science \& Technology Education, 3(2), 149-156.

20. Turnbull, A. (2006). Children's Transitions: A Literature Review. Retrieved 10 Sep 2015, from http://www.cambridgeshire.gov.uk/NR/rdonlyres/0F47EDD3-B534-4319-9F8C70870DCF42E4/0/CHILDRENSTRANSITIONS.pdf

21. Uwezo (2012). Where are our Children Learning? School Quality and Learning in Kenya. policy brief KE01/2012E. 